\title{
Успішне хірургічне лікування паціента з аорто-кавальною норицею на фоні розшаровуючої інфраренальної аневризми черевного відді.лу аорти без гемотрансфузії (огляд літератури та опис клінічного випадку)
}

\begin{abstract}
Розшарування аневризми черевної аорти в нижню порожнисту вену - рідкісне і дуже тяжке ускладнення, зустрічається приблизно в 1 \% випадків розривів аневризми. Певна група пацієнтів відмовляється від переливання крові та її компонентів, як правило, на основі релігійних переконань і віри. Такі обмеження ускладнюють роботу як анестезіологів, так і хірургів, особливо під час операційних втручань, які супроводжуються значною крововтратою. Автоматизовані системи для реінфузії відмитих еритроцитів, засновані на технології Cell Saver, дозволяють збирати кров безпосередньо з операційної рани в стерильну ємність із фільтром за допомогою вакуумного відсмоктування, і в подальшому повертати пацієнту. Даний метод можна вважати альтернативою використання донорської крові.
\end{abstract}

Ключові слова: аорто-кавальна фістула; аортографія; перфторан; автологічна реінфузія; апарат “Cell Saver”.

Ускладнені аневризми черевної аорти (АЧА) виявляють у 3-7 \% пацієнтів із аневризмами, тоді як післяопераційна летальність сягає 80 \% [5]. Розшарування АЧА в нижню порожнисту вену (НПВ) - рідкісне і дуже тяжке ускладнення, зустрічається приблизно в 1 \% випадків розривів аневризми [9]. Перше повідомлення про аортокавальну норицю (АКН) описав Р. Symе ще в 1831 р. [15]. Причинами розриву стінки між двома судинами, що призводить до розвитку АКН, у 15 \% випадків є проникаючі травми та у 5 \% ятрогенія (наприклад, діагностична лапаротомія та поперекова ламінектомія) [18, 13]. До інших рідкісних причин відносять мікотичні аневризми, артеріїт Такаясу, синдром Елерс-Данлоса і Марфана [7, 14, 16].

Патофізіологія змін, що відбуваються при вираженому артеріовенозному скиданні, характеризується формуванням патологічного додаткового кола кровообігу, так званого “фістульного”, внаслідок чого відбувається зміна центральної і регіонарної гемодинаміки [2]. Зміни центральної гемодинаміки полягають в перевантаженні правих відділів серця об’ємом та розвитком клініки правошлуночкової недостатності. Наявність патологічного артеріовенозного сполучення (АВС) призводить до тяжкої, що погано піддається корекції, а часом, незворотної серцевої недостатності (CH). На сьогодні в літературі можна зустріти поодинокі публікації про лікування АКН [4]. За даними літератури, летальність при відкритому хірургічному лікуванні хворих складає 30 \%, причиною, здебільшого, є масивна крововтрата [8]. Хірургічне лікування АКВ пов’язане з високим ризиком смертності через непередбачувану крововтрату і розвиток поліорганної недостатності. Періопераційна летальність сягає 20-60 \% [12, 17]. Інтраопераційна крововтрата $є$ фактором ризику як загальних, так і кардіальних ускладнень.

Певна група пацієнтів відмовляється від переливання крові та ії компонентів, як правило, на основі релігійних переконань і віри (наприклад, свідки Єгови). Часто дана категорія хворих згідна на автологічне переливання крові при забезпеченні безперервності з системою кровообігу пацієнта протягом всього часу переливання [10]. Такі обмеження ускладнюють роботу як анестезіологів, так і хірургів, особливо під час операційних втручань, які супроводжуються значною крововтратою. Важливо пояснити всі наявні варіанти пацієнтам, які відмовляються від переливання крові та її компонентів.

Автоматизовані системи для реінфузії відмитих еритроцитів, засновані на технології Cell Saver дозволяють збирати кров безпосередньо 3 операційної рани, за допомогою вакуумного відсмоктування в стерильну ємність з фільтром, і в подальшому повертати пацієнту [3].

Наводимо клінічне спостереження вдалого лікування пацієнта з приводу АКН та хибної аневризми аорти.

Пацієнт Д., 67 років, в листопаді 2016 р. госпіталізований у відділення хірургії судин Закарпатської обласної клінічної лікарні імені А. Новака із скаргами на біль в епігастральній ділянці живота, наявність пухлиноподібного пульсуючого утвору в череві, загальну слабість, задишку при незначному фізичному навантаженні, тахікардію. 
При госпіталізації пацієнт надав документ “Жодної крові”.

При об'єктивному огляді: шкірні покриви та видимі слизові блідого кольору. Серце - тони ослаблені, діяльність ритмічна. Пульс - 100 уд./хв, ритмічний. АТ-120/80 мм рт. ст. Локальний статус: у черевній порожнині (зліва нижче від пупка) пальпується пульсуючий пухлиноподібний утвір розміром 6,0 х 5,0 см. Має місце шумова симптоматика над утвором. Пульс на всіх сегментах задовільний. Набряк лівої гомілки та стегна.

Загальний аналіз крові під час госпіталізації (26.11.16р.): гемоглобін 92 г/л, еритроцити $3,5 \times 10^{12} /$ л, лейкоцити $10 \times 10^{9}$ /л, глюкоза - 5,8 ммоль/л; біохімічний аналіз: сечовина 15,50 ммоль/л, креатинін 233,35 мколь/л, загальний білок 52,5 г/л, білірубін загальний 11,81 мкмоль/л.

За даними МСКТ ОЧП виявлено аневризму лівої загальної клубової артерії (ЗКВ).

За даними ЕхоКС: дилатація всіх камер серця, ознаки легеневої гіпертензії, СТЛА 50 мм. рт. ст.

Встановлено клінічний діагноз: хибна розшаровуюча аневризма біфуркації аорти, аортокавальна нориця (між інфраренальним відділом ЧА та ЗКВ зліва), посттромбофлебітична хвороба лівої нижньої кінцівки, набряково-больова форма, хронічна венозна недостатність лівої н/к. Синдром нижньої порожнистої вени. IXС. Кардіосклероз атеросклеротичний. Фібриляція передсердь, пароксизмальна форма. XCH II-III ст. Гіпертонічна хвороба, II ст., ризик високий. Вторинна нормохромна анемія середньої тяжкості. Легенева гіпертензія середнього ступеня, ДН 2 ст. Правостороння нижньочасткова пневмонія.

В клініці прийнято рішення про необхідність усунення патологічного артеріовенозного скиду хірургічно.

Опис операції. 09.12.16 р. хворому проведено тотальну внутрішньовенну анестезію з інтубацією трахеї. Виконано повну серединну лапаротомію, в черевній порожнині невелика кількість асцитичної рідини солом'яно-жовтого кольору. При ревізії виявлено: пульсуючий утвір в області біфуркації аорти, в який втягнуто біфуркація аорти, початкові відділи клубових артерій, НПВ та ліва ЗКВ. Розмір утвору 8,0 х 10,0 х 8,0 см. Діаметр аорти - 2,0 см, НПВ - 4,5 см, лівої ЗКВ - 5,0 см. На дні хибної аневризми є розрив загальної клубової артерії (ЗагКА) зліва та отвір по передній стінці загальної клубової вени (ЗагКВ) зліва. Для мобілізації НПВ та ЗагКВ прийнято рішення пересікти аорту та ЗагКА справа. ЗагКВ зліва виділена на протязі. Після перетискання НПВ виконано резекцію пошкодженої ділянки ЗагКВ. На першому ета- пі виконали алопротезування ЗагКВ зліва. Сформували дистальний анастомоз: “кінець протеза у кінець зовнішньої клубової вени” та проксимальний анастомоз: “кінець протеза у бік НПВ”. Другим етапом виконали аортоклубове біфуркаційне алопротезування. Загальна крововтрата становила близько 5 л крові.

Операційне втручання проводили за допомогою апарату “Cell Saver Medtronic” (США).

Втрачену під час операції кров збирають відсмоктувачем, після чого кров змішують 3 антикоагулянтом і надходить в резервуар, де фільтруються дрібні шматочки тканин, згустки крові та інші макроструктури. 3 резервуара за допомогою перистальтичного насоса кров потрапляє у центрифугу. Еритроцити зв'язуються в центрифузі відцентровими силами, тоді як плазма виділяється 3 центрифуги, вимиваючи вільний гемоглобін, антикоагулянт, активовані фактори згортання та активовані тромбоцити. Як тільки гематокрит крові, що міститься в центрифузі, досягає $55 \%$, туди починає надходити фізіологічний розчин, промиваючи еритроцити. Після закінчення циклу промивання концентрована суспензія еритроцитів у фізіологічному розчині надходить у мішок для реінфузії (схема).

Інтраопераційно проведено фільтрацію 4500 л “крові”. Відмито та внутрішньовенно повернено до пацієнта 1360 мл відмитих еритроцитів. Внутрішньовенно перелито хворим 2000 мл колоїдів та 200 мл перфторану.

Через 10 годин після операційного втручання хворий екстубований, дихання самостійне, вільне, $\mathrm{SpO}_{2} 99$ \% з інгаляцією кисню. Хворий в свідомості; гемодинаміка стабільна; рівень гемоглобіну 79 г/л, еритроцити 2,5 т/л, загальний білок 39 г/л.

У післяопераційному періоді хворий отримував комплексне лікування згідно з протоколами, додатково перфторан 200,0 (одноразово), розчини амінокислот, збалансоване парентеральне харчування (трикомпонентна суміш).

Пацієнта виписали в задовільному стані, з покращенням, під амбулаторний нагляд хірурга.

АКВ на тлі ускладненої АЧА - це швидко прогресуюче захворювання, яке супроводжується серцевою недостатністю в стадії декомпенсації та потребує від операційної бригади концентрації, навичок, досвіду, оскільки фактор часу має вирішальне значення. Подібні результати операційних втручань отримали П. І. Никульников та співавтори, вони описують клінічний виподок, де інтраопераційна крововтрата становила 5000 мл. Перелито до 2000 мл еритроцитарної маси, 700 мл свіжозамороженої плазми, та 8000 мл колоїдів [7]. 


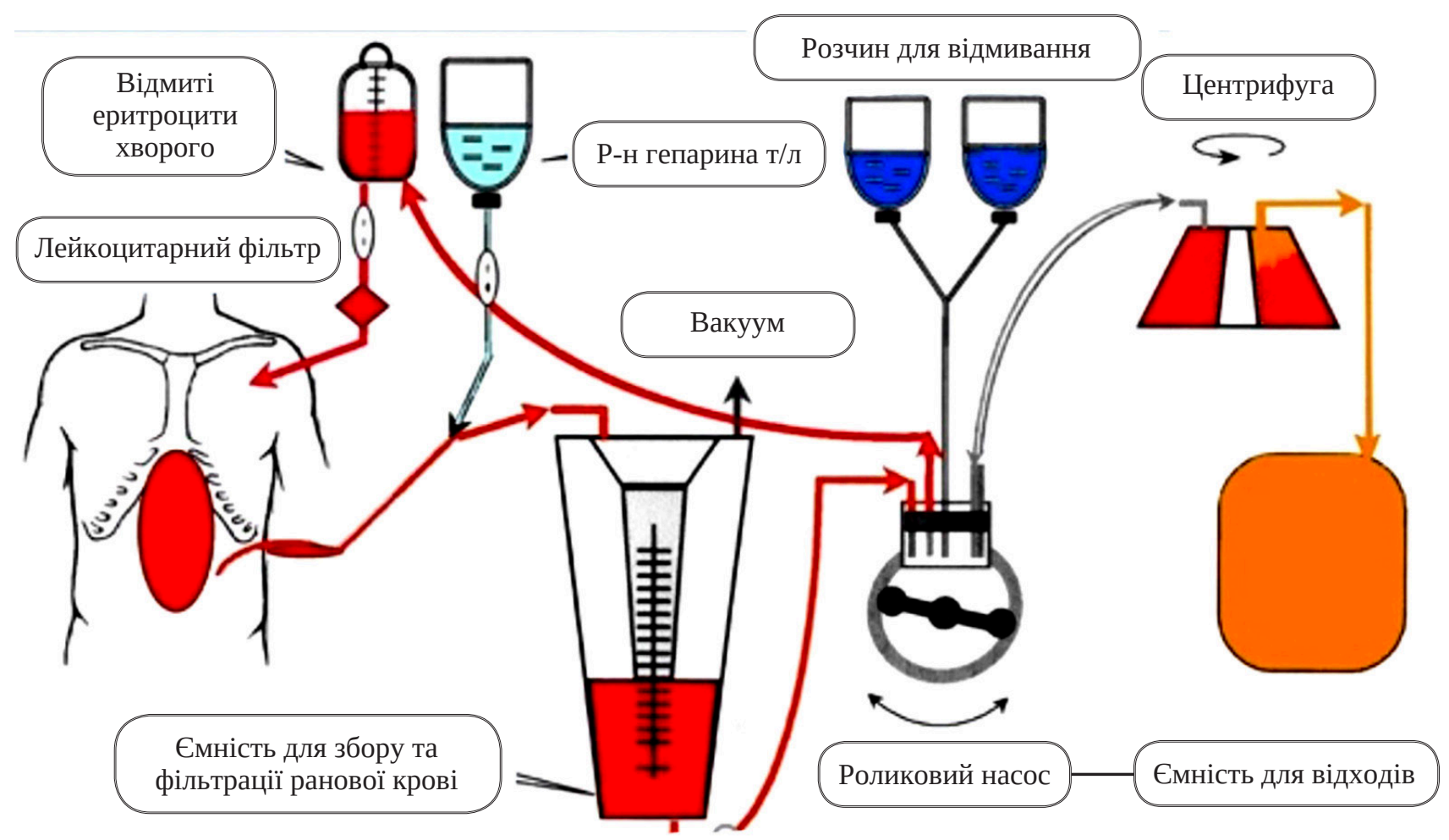

Схема. Схема реінфузії крові Cell Saver.

Комаров Р. Н. та співавтори описують, що інтраопераційна крововтрата при відкритому хірургічному лікуванні АКН склала 4000 мл, які були компенсовані 3 дозами донорської крові та 3 дозами плазми, а також реінфузією за допомогою апарата "Cell Saver" еритроцитів до 2100 мл [5].

За результатами дослідження В. В. Катинов та співавтори, методом реінфузії автоеритроцитів та трансфузії донорської крові досягається практично повне заміщення крововтрати 95,6 \%, при звичайній реінфузії заміщається 30,4 \% [2].

На думку Г. Г. Хулубава та співавторів, заповнення кровтрати має виконуватися у співвідношенні 1: 1 і найбільш оптимальним методом $є$ використання автоінфузії [15].

\section{СПИСОК ЛІТЕРАТУРИ}

1. Оптимизация хирургического лечения аневризм брюшной аорты в сочетании с ишемической болезнью сердца / В. В. Катынов, О. Е. Логинов, П. Н. Кордатов [и др.] // Клиническая медицина. - 2013. - Т. 5, № 3. - С. 63-68.

2. Посттравматические артериовенозные фистулы. Опыт лечения / Л. М. Чернуха, П. И. Никульников, Е. В. Каширова [и др.] // Новости хирургии. - 2011. - Т. 19, № 3. - С. 63-69. 3. Проблема операционной кровопотери и применение современных кровосберегающих методик в нейроанестезиологии / А. Ю. Лубнин, В. В. Громова // Анестезиология и реаниматология. - 2003. - № 3. - С. 26-30.

4. Устранение посттравматического артериовенозного сбро-
Формування аортокавальних нориць призводить до змін системної гемодинаміки, зумовлене скидом крові з артеріальної у венозну системи, що може призвести до формування декомпенсації життєво важливих органів.

Кількість пацієнтів, яким не можна переливати кров та її компоненти, зростає у всьому світі. Ведення таких хворих супроводжується значними труднощами. При лікуванні свідків Єгови потрібно враховувати певні етичні та правові аспекти, при цьому зберегти життя шляхом забезпечення нормоволемії та адекватного постачання кисню. Тому використання методу реінфузії автоеритроцитів за допомогою апарата "Cell Saver" є альтернативою використання донорської крові.

са между правой общей подвздошной артерией и нижней полой веной / Р. Н. Комаров, О. А. Виноградов, Н. В. Яснопольская [и др.] // Кардиология сердечно-сосудистая хирургия. 2016. - Т. 9, № 4. - С. 81-85.

5. Хирургическое лечение аневризм брюшной аорты / А. А. Спиридонов, В. С. Аракелян, Е. Г. Тутов, Т. В. Сухарева. - М. : Изд-во НЦССХ им. А. Н. Бакулева РАМН, 2005. -294 c.

6. Хирургическое лечение аортокавальной фистулы на фоне расслаивающей инфраренальной аневризмы брюшной части аорты / П. И. Никульников, А. Н. Быцай, А. И. Яценко, И. Б. Бурая // Клінічна хірургія. - 2015. - № 11. - С. 74-76. 
7. Belyavskaya T. Ruptured aortic aneurysm complicated by aortocaval fistula due to salmonella infection / T. Belyavskaya, A. Baumann // Eur. J. Vasc. Endovasc. Surg. - 2016. - Vol. 51. - P. 25.

8. Brightwell R. E. Aortocaval fistula: current management strategies / R. E. Brightwell, V. Pegna, N. Boyne // ANZ Journal of Surgery. - 2013. - Vol. 83 (1-2). - P. 31-35. doi: 10.1111/ j.1445-2197.2012.06294.

9. Endovascular treatment of ruptured abdominal aortic aneurysm with aortocaval fistula / G. Guzzardi, R. Fossaceca, I. Divenuto [et al.] // Cardiovasc. Intervent. Radiol. - 2010. Vol. 3. - P. 853-856.

10. Hughes D. B. The contemporary approach to the care of Jehovah's witnesses / D. B. Hughes, B. W. Ullery, P. S. Barie // J. Trauma. - 2008. - Vol. 65. - P. 237-247.

11. Хубулава Г. Г. Хирургическое лечение аневризмы инфраренального отдела аорты / Г. Г. Хубулава, А. Б. Сазонов. Санкт-Петербург, 2009. - 144 с.

12. Immediate endovascular treatment of an aortoiliac aneurysm ruptured into the vena cava / R. Kopp, R. Weidenhagen, R. Hoffman [et al.] // Ann. Vasc. Surg. - 2006. - Vol. 20. - P. 525-528.

\section{REFERENCES}

1. Katynov, V.V., Loginov, O.Ye., Kordatov, P.N., Maksimov, A.L., Ryazanov, M.V., Chebotar, Ye.V., ..., Koroleva, B.A. (2012). Optimizatsiya khirurgicheskogo lecheniya anevrizm bryushnoy aorty $\mathrm{V}$ sochetanii $\mathrm{s}$ ishemicheskoy boleznyu serdtsa [Optimization of the surgical treatment of abdominal aortic aneurysms in combination with coronary heart disease]. Klinicheskaya meditsina - Clinical Medicine, 5, 63-68 [in Russian]. 2. Chernukha, L.M., Nikulnikov, P.I., Kashirova, Ye.V., Vlaykov, G.G., Altman, I.V., Guch, A.A., \& Matyashchuk, A.S. (2011). Posttravmaticheskiye arteriovenoznyye fistuly. Opyt lecheniya [Post-traumatic arteriovenous fistulas. Treatment experience]. Novosti khirurgii - News of Surgery, 19, 3, 63-69 [in Russian].

3. Lubnin, A.Yu., \& Gromova, V.V. (2003). Problema operatsionnoy krovopoteri i primeneniye sovremennykh krovosberegayushchikh metodik $\mathrm{v}$ neyroanesteziologii [The problem of operating blood loss and the use of modern blood-saving techniques in neuroanesthesiology]. Anesteziologiya i reanimatologiya Anesthesiology and Reanimatology, 3, 26-30 [in Russian].

4. Komarov, R.N., Vinogradov, O.A., Yasnopolskaya, N.V., Dzyundzya, A.N., \& Nagornyy, M.N. (2016). Ustraneniye posttravmaticheskogo arteriovenoznogo sbrosa mezhdu pravoy obshchey podvzdoshnoy arteriyey i nizhney poloy venoy [Elimination of post-traumatic arteriovenous discharge between the right common iliac artery and the inferior vena cava]. Kardiologiya serdechno-sosudistaya khirurgiya - Cardiology Cardiovascular Surgery, 4, 81-85 [in Russian].

5. Spiridonov, A.A., Arakelyan, V.S., Tutov, Ye.G., \& Sukhareva, T.V. (2005). Khirurgicheskoye lecheniye anevrizm bryushnoy aorty [Surgical treatment of abdominal aortic aneurysms]. Moscow: Izdatelstvo NCSSH im. A. N. Bakuleva RAMN [in Russian].

6. Nikulnikov, P.I., Bytsay, A.N., Yatsenko, A.I., \& Buraya, I.B. (2015). Khirurgicheskoye lecheniye aortokavalnoy fistuly na fone rasslivayushchey infrarenalnoy anevrizmy bryushnoy chasti aorty [Surgical treatment of the aortocaval fistula with a dissolving infrarenal aneurysm of the abdominal part of the aorta]. Klinichna khirurhiia - Clinical Surgery, 11, 74-76 [in Russian].

7. Belyavskaya, T., \& Baumann, A. (2016). Ruptured aortic aneurysm complicated by aortocaval fistula due to salmonella
13. Inflammatory infrarenal aortic aneurysm with aortocaval fistula / E. Laxdal, K. Søvik, G. Pedersen, S. Aune // Ann. Vasc. Surg. - 2007. - Vol. 21. - P. 633-636.

14. Aortocaval fistula / B. Lorenzati, M. Perotto, S. Bottone [et al.] // Intern. Emerg. Med. - 2014. - Vol. 9. - P. 895-896.

15. Orion K. C. Aortocaval fistula: is endovascular repair the preferred solution? / K. C. Orion, R. J. Beaulieu, J. H. Black // Ann. Vasc. Surg. - 2016. - Vol. 31. - P. 221-228.

16. Clinical manifestations of aortocaval fistulas in ruptured abdominal aortic aneurysm: report of two cases / E. D. Psathas, S. Lioudaki, M. Doulaptsis [et al.] // Case Rep. Surg. - 2012. 2012. - ID 123081. - 4 p.

17. A case of unilateral leg edema due to abdominal aortic aneurysm with aortocaval fistula / T. Takaseya, S. Hiromatsu, H. Akashi [et al.] // Ann. Thorac. Cardiovasc. Surg. - 2007. Vol. 13. - P. 135-138.

18. Aortocaval fistula resulting from rupture of abdominal aortic dissecting aneurysm treated by delayed endovascular repair: a case report / T. Wang, B. Huang, J. Zhao [et al.] // Medicine. 2016. - Vol. 95. - P. e3570.

infection. Eur. J. Vasc. Endovasc. Surg., 51, 25.

8. Brightwell, R.E., Pegna, V., \& Boyne, N. (2013). Aortocaval fistula: current management strategies. ANZ Journal of Surgery, 83 (1-2), 31-35. doi: 10.1111/j.1445-2197.2012.06294.

9. Guzzardi, G., Fossaceca, R., Divenuto, I., Musiani, A., Brustia, P., \& Carriero, A. (2010). Endovascular treatment of ruptured abdominal aortic aneurysm with aortocaval fistula. Cardiovasc. Intervent. Radiol., 33, 853-856.

10. Hughes, D.B., Ullery, B.W., \& Barie, P.S. (2008). The contemporary approach to the care of Jehovah's witnesses. $J$. Trauma, 65, 237-247.

11. Khubulava, G.G., \& Sazonov, A.B. (2009). Khirurgicheskoe lechenie anevrizm infrarenalnogo otdela aorty [Surgical treatment of aneurysm of the infrarenal aorta]. Saint Petersburg [in Russian]. 12. Kopp, R., Weidenhagen, R., Hoffman, R. Waggershauser, T., Meimarakis, G., Andrassy, J., ..., \& Jauch, K.W. (2006). Immediate endovascular treatment of an aortoiliac aneurysm ruptured into the vena cava. Ann. Vasc. Surg., 20, 525-528.

13. Laxdal, E., Søvik, K., Pedersen, G., \& Aune, S. (2007). Inflammatory infrarenal aortic aneurysm with aortocaval fistula. Ann. Vasc. Surg., 21, 633-636.

14. Lorenzati, B., Perotto, M., Bottone, S., Tenconi, G., Gazzina, G., \& Cataldi, W. (2014). Aortocaval fistula. Intern. Emerg. Med., 9, 895-896.

15. Orion, K.C., Beaulieu, R.J., \& Black, J.H. (2016). Aortocaval fistula: is endovascular repair the preferred solution? Ann. Vasc. Surg., 31, 221-228.

16. Psathas, E.D., Lioudaki, S., Doulaptsis, M., Charalampoudis, P., Klonaris, C., \& Verikokos, C. (2012). Clinical manifestations of aortocaval fistulas in ruptured abdominal aortic aneurysm: report of two cases. Case Rep. Surg. 2012, ID 123081, 4.

17. Takaseya, T., Hiromatsu, S., Akashi, H., Okazaki, T., Tobinaga, S., \& Aoyagi, S. (2007). A case of unilateral leg edema due to abdominal aortic aneurysm with aortocaval fistula. Ann. Thorac. Cardiovasc. Surg., 13, 135-138.

18. Wang, T., Huang, B., Zhao, J., Yang, Y., \& Yuan, D. (2016). Aortocaval fistula resulting from rupture of abdominal aortic dissecting aneurysm treated by delayed endovascular repair: a case report. Medicine, 95, e3570.

Отримано 19.06.2019 
Uzhhorod National University

\title{
SUCCESSFUL SURGICAL TREATMENT OF A PATIENT WITH AORTO-CAVAL FISTULA ON THE BACK- GROUND OF A STRATIFIED INFRARENAL ANEURYSM OF THE ABDOMINAL AORTA WITHOUT HE- MOTRANSFUSION (LITERATURE REVIEW AND GLINICAL CASE DESCRIPTION)
}

\begin{abstract}
Dissection of an abdominal aortic aneurysm into the inferior vena cava is a rare and very severe complication, occurring in about $1 \%$ of cases. A particular group of patients refuses transfusion of blood and it's components, usually because of religious beliefs. Such restrictions complicate the work of both anesthesiologists and surgeons, especially during surgery, which is accompanied by significant blood loss. Automated erythrocyte re-infusion systems based on Cell Saver technology allow blood to be collected directly from the operating wound into a sterile container with a filter and then returned to the patient. This method can be considered as an alternative to the transfusion of donor blood.
\end{abstract}

Key words: aorto-caval fistula; aortography; perftoranum; autologous reinfusion; Cell Saver device.

М. М. ИВАЧЕВСКИЙ, В. В. ИВАЧЕВСКАЯ, И. В. ПИСАРЕНКО

гВУз “Ужгородский национальный университет”

\section{УСПЕШНОЕ ХИРУРГИЧЕСКОЕ ЛЕЧЕНИЕ ПАЦИЕНТА С АОРТО-КАВАЛЬНЫМ СВИЩЕМ НА ФОНЕ РАСС.АИИАЮШЕЙ ИНФРАРЕНАЛЬНОЙ АНЕВРИЗМЫ БРЮШНОГО ОТДЕЛА АОРТЫ БЕЗ ГЕМОТРАНСФУЗИИ (ОБЗОР ЛИТЕРАТУРЫ И ОПИСАНИЕ КЛИНИЧЕСКОГО С.УУАЯ)}

\begin{abstract}
Расслоение аневризмы брюшной аорты в нижнюю полую вену - редкое и очень тяжелое осложнение, встречается примерно в 1 \% случаев разрывов аневризмы. Определенная группа пациентов отказывается от переливания крови и ее компонентов, как правило, на основе религиозных убеждений и веры. Такие ограничения затрудняют работу как анестезиологов, так и хирургов, особенно во время оперативных вмешательств, которые сопровождаются значительной кровопотерей. Автоматизированные системы для реинфузии отмытых эритроцитов, основанные на технологии Cell Saver, позволяют собирать кровь непосредственно из операционной раны в стерильную емкость с фильтром с помощью вакуумного отсоса, и в дальнейшем возвращать пациенту. Данный метод можно считать альтернативой использования донорской крови.
\end{abstract}

Ключевые слова: аорто-кавальная фистула; аортография; перфторан; аутологическая реинфузия; аппарат “Cell Saver”. 